\title{
PHYSICAL, CHEMICAL AND MORPHOLOGICAL CHARACTERISTICS OF BAMBOO SPECIES GUADUA TRINII AND GUADUA ANGUSTIFOLIA AND THEIR POTENTIAL TO PRODUCE HIGH-VALUE PRODUCTS
}

\author{
AGATHA E. R. PRADO GÁRATE, ${ }^{*, * *}$ FERNANDO ESTEBAN FELISSIA, ${ }^{* * *}$ \\ MARIA CRISTINA AREA, ${ }^{* * *}$ TERESA SUIREZS ${ }^{* * *}$ and MARÍA EVANGELINA VALLEJOS ${ }^{* * *}$ \\ "Círculo de Investigación del Bambú, Universidad Nacional Agraria La Molina (UNALM), \\ Av. La Molina s/n, 12 (15026) Lima, Perú \\ ***IMAM, UNaM, CONICET, Facultad de Ciencias Forestales (FCF), \\ Bertoni $124 \mathrm{~km} 3$ (3380) Eldorado, Argentina \\ *** IMAM, UNaM, CONICET, FCEQYN, Programa de Celulosa y Papel (PROCyP), \\ Félix de Azara 1552 (3300) Posadas, Argentina \\ $₫$ Corresponding author: M. E. Vallejos, mariaxvallejos@gmail.com
}

Received June 17, 2021

\begin{abstract}
High-value products can be obtained from non-traditional lignocellulosic resources, such as bamboo, taking full advantage of these materials through efficient, low-cost and low-pollution fractionation processes. This work aims to analyze the physical, chemical, and morphological differences between two bamboo species as a rapidly growing resource of great regional interest - Guadua trinii and Guadua angustifolia. Both samples were characterized in terms of basic density, morphological characteristics, and chemical composition. This work shows that $G$. trinii has a significantly denser woody structure, with a uniform density at the sampled culm height. The internal structure consists of a parenchyma matrix and vascular bundles composed of parenchyma cells and fiber bundles. G. angustifolia has significantly longer fibers. Chemical characterization showed differences between the carbohydrate and lignin contents. The results of this work are critical to know the potential of both bamboo species as a source of high-value products in the bamboo biorefinery framework.
\end{abstract}

Keywords: Guadua angustifolia, Guadua trinii, chemical composition, morphology, lignocellulosic fiber

\section{INTRODUCTION}

Non-wood cellulosic fiber sources are relevant alternatives to affront the growing demand for raw materials owing to the decrease in wood resources worldwide. This high demand has intensified the study of renewable alternative raw materials for the energy, chemical, and pharmaceutical industries and biomaterials. ${ }^{1,2}$ Lignocellulosic biomass is expected to become the most significant biomass source in the future, as it presents moderate costs and less competition with food production. ${ }^{3,4}$ In this context, traditional pulp and paper producers, concentrated in tropical and subtropical regions, have recent technologies, higher production capacities, and lower raw material and labor costs. In these regions, a wide variety of annual crops (sisal, bamboo and others) and agroforestry residues (sugarcane bagasse, wood sawdust, cereal straws are just a few of them) are also available with great potential as a fibrous resource due to their rapid growth/production, low cost and renewability.,

Currently, it is estimated that the price of forest products could continue to decrease due to competition on the global market. Therefore, forest producers adopted innovative strategies to increase their income through the production of bioenergy and biomaterials, in addition to wood, pulp, and paper products. One of these strategies is adopting the biorefinery concept, taking advantage of the high concentration of raw materials in the forest industry. Besides, it has the necessary infrastructure to create technological biorefinery schemes.

Biorefineries are a real opportunity to improve the profitability of companies processing lignocellulosic materials. A clear example is the 
current trend in the global pulp and paper industry to diversify its conventional production (cellulosic pulp and paper products) by developing and commercializing new products (nanocellulose, biomaterials, fermentable sugars for ethanol, lignin, among others).

Bamboo (Guadua genus) is a relevant lignocellulosic fiber resource in many tropical and subtropical regions (principally China). Currently, China counts on almost 4.5 million hectares of Phyllostachys pubescens plantations. ${ }^{7}$

In Latin America, Peru has promoted the Guadua angustifolia or Guayaquil cane plantations since 2005, using a Colombian propagation technique that increased the planted area from 3,000 ha to more than 10,000 ha in 12 years. These plantations are destined to the market for whole and rolled cane (6 m long), whose price (without added value) is around USD 0.5 to 3 per cane, and which is mainly used in construction (terrace extensions, country houses, agricultural warehouses etc.). Almost $90 \%$ of the bamboo comes from plantations, and its price could reach up to USD 10 per cane. Despite the 2008 crisis, this market has continued to grow, even in competition with China, which cultivates other types of bamboo. Guadua trinii grows in the Misiones or Paranaense jungle (Argentina), forming dense thickets that are impossible to penetrate. ${ }^{8}$ This species is used to construct the walls of precarious rural dwellings (ranchos) $;^{9,10}$ there are also antecedents of its use in the paper industry. ${ }^{11}$

The bamboo market is still inceptive and complex. Bamboo has traditionally been used as a construction material and in handicrafts due to its rapid growth, high resistance, surface hardness, and easy machinability. Its production is dispersed, forming a much-intertwined market between merchants, producers, transporters, and the official authority.

The woody structure of Guadua is simpler than that of wood and the plant is harvested after 4 years. Its diameter can reach $17 \mathrm{~cm}$, and its interior is hollow with a stem thickness of 15-18 $\mathrm{mm}$. The height of the stem can measure up to 25 $\mathrm{m}$, although it depends on the region where it is grown. In the Province of Mala (south of Lima), it can reach $16 \mathrm{~m}$ in altitudinal floors between 900 to 1400 meters above sea level, as occurs in the Northeastern zone (Cajamarca, Amazonas, and San Martín) and the central jungle (Pasco, Junín). In 2016, the Universidad Agraria La Molina de Peru (UNALM), with some institutional partners, installed the Circle of Research of Bamboo (Círculo de investigación del Bambú, CIB) to promote research in 3 fields: (i) the value chain and markets, (ii) taxonomy and ethnobotany, and (iii) transformation and valorization technology.

G. angustifolia is one of the hardest species, reaching a basic density of up to $700 \mathrm{~kg} / \mathrm{m}^{3}$. G. chacoensis (tacuara cane), growing wild in Paraguay and the northwest region of Argentina (Misiones and Corrientes), is a similar species. ${ }^{12}$ G. trinii has defined rhizomes (pachymorphs) and a height up to $8-10 \mathrm{~m}$. Its cane is hollow, with a diameter of $3-5 \mathrm{~cm}$ and a thickness of $5-7 \mathrm{~mm} .{ }^{13}$ It is present in southern Brazil, Uruguay, and Argentina (Buenos Aires, Corrientes, Entre Ríos and Misiones).

In recent years, research has focused on structural and semi-structural applications of bamboo, such as its use as a reinforcement fiber in polymeric matrix composite materials. ${ }^{14}$ These studies showed that bamboo fiber could be used as a type of reinforcement in composite materials due to its good mechanical properties. Some of these studies have indicated that the tensile strength and modulus of bamboo fibers were almost twice higher than those of pine fibers and significantly higher than other coniferous fibers due to the unique cell wall structure. ${ }^{15}$ However, the variability between bamboo species and the few investigations to elucidate the structural, morphological, chemical, and physical differences and the size distribution of its fibers have limited its applications as a fibrous resource of industrial interest.

The objective of this study was to characterize physically, chemically, and morphologically two bamboo species: $G$. trinii and $G$. angustifolia. These fast-growing resources of great regional interest could be used as non-traditional lignocellulosic resources to produce high-value products in a biorefinery framework.

\section{EXPERIMENTAL}

\section{Sample collection and preparation}

$G$. trinii sample, provided for IMAM-FCF (Eldorado, Argentina), was locally collected. $G$. angustifolia sample was provided for the Círculo del Bambú (UNALM, Perú). Both four-year-old Guadua samples were representatively selected, cut, and sent to the laboratory. There, they were characterized by physical, structural, and chemical analysis.

\section{Basic density}

The basic density of the stems was determined according to ISO Standard 22157-1. The bamboo 
culms were divided into three parts of 1.5 meters each, starting from the cutting line in the base, middle, and top. From each of these parts, 12 pieces of $25 \times 25 \mathrm{~mm}$ were extracted. The basic density $\left(\mathrm{g} / \mathrm{cm}^{3}\right)$ was determined for each portion by the ratio between the dry weight and its green or water-saturated volume. The green volume of the pieces was found by the Archimedes method.

Culm and fiber morphology

\section{Analysis of the histological sections of the stem}

Representative samples from the middle part of the culm (annular shape) were separated and cut into thin slices using a microtome. The tangential, transverse, and radial histological sections were obtained. These slices were observed with a Leika-360 optical microscope to analyze both fibers and vascular elements.

\section{Biometric analysis of disaggregated fibers}

Both species were treated with a solution of chlorine dioxide and sodium carbonate to obtain fiber disaggregates (individualized fibers). These disaggregates were diluted with water to generate a fibrous suspension. Average fiber length and width were determined using a fiber quality analyzer (FQA360, OpTest Equipment) according to ISO Standard 16065.

Fiber and lumen widths were measured in safraninstained fiber preparations using an optical microscope connected to a camera with an image analyzer. A total of 200 fibers (width and lumen) were measured (two measurements for each fiber) to determine the average width. Wall thickness was calculated by the difference between the two width values.

\section{Chemical composition}

The chemical composition of both species was determined by total extractives, structural carbohydrates, total lignin, and ash contents. The standard analytical methods for biomass of the National Renewable Energy Laboratory (NREL) were used: "Preparation of Samples for Compositional Analysis" NREL/TP-510-42620, "Determination of Extractives in Biomass" NREL/TP-510-42619, "Determination of Ash in Biomass" NREL/TP-510 42622," Determination of Structural Carbohydrates and Lignin in Biomass" NREL/TP -510-42618. Carbohydrates were quantified by HPLC liquid chromatography with refractive index detectors and a diode array using an Aminex-HPX87H column (BIORAD).

\section{RESULTS AND DISCUSSION}

The basic density was measured at three different culm heights for each species. The average values are presented in Table 1 .

$G$. trinii has a dense woody structure, with a uniform basic density at the sampled height. On the contrary, the basic density of $G$. angustifolia significantly varies with height in the same individual, being denser at middle height. The graph of means for basic density (ANOVA, 95\% LSD) shows the variance of the basic densities for both bamboo species (Fig. 1).

Table 1

Basic density $\left(\mathrm{g} / \mathrm{cm}^{3}\right)$ determined at different culm heights

\begin{tabular}{lcc}
\hline Height & G. $_{\text {trinii }}{ }^{*}$ & G. $_{\text {angustifolia }}{ }^{*}$ \\
\hline Base & $0.53 \pm 0.023$ & $0.38 \pm 0.013$ \\
Middle & $0.52 \pm 0.023$ & $0.49 \pm 0.020$ \\
Top & $0.55 \pm 0.009$ & $0.38 \pm 0.162$ \\
\hline Media & $0.53 \pm 0.023$ & $0.42 \pm 0.055$ \\
\hline
\end{tabular}

*Average basic density, 12 samples were measured for each height
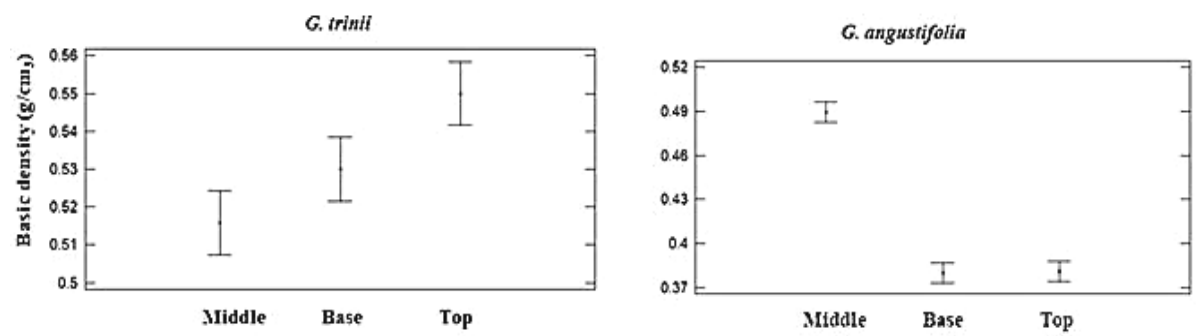

Figure 1: Basic density means and 95\% LSD intervals of ANOVA differences between heights 


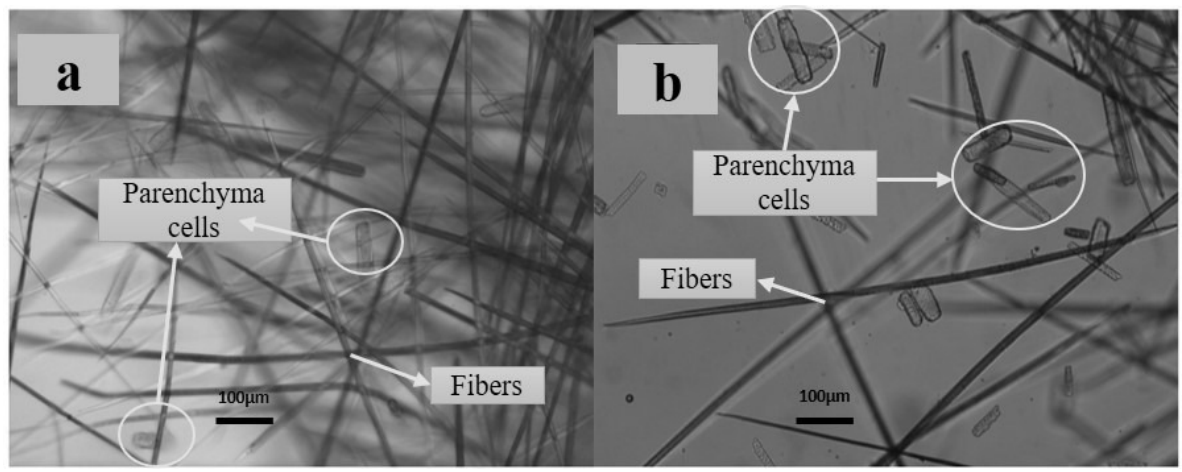

Figure 2: Disaggregates of fibers from (a) G. trinii and (b) G. angustifolia

The basic density values determined in this study for both species are in the range reported by other authors for bamboos $\left(0.5\right.$ and $\left.0.9 \mathrm{~g} / \mathrm{cm}^{3}\right)-$ G. trinii $\left(0.53 \mathrm{~g} / \mathrm{cm}^{3}\right)$, and $G$. angustifolia $(0.45$ $\left.\mathrm{g} / \mathrm{cm}^{3}\right) .^{12,16}$ In both cases, it is in the optimal range defined to produce cellulosic pulp (0.45 and 0.55 $\left.\mathrm{g} / \mathrm{cm}^{3}\right) .{ }^{17}$ Higher bamboo densities mean a greater mass of fibrous raw material in a given digester volume, providing a higher yield in pulp production. However, species with a basic density higher than the indicated range will present impregnation difficulties, demanding a higher alkali load in the chemical pulping process. $^{18}$ Generally, bamboo density increases with age, and it is estimated that the ideal age for its use as fibrous raw material is between 2 and 4 years old. ${ }^{18,19}$ The species studied are 4-year-old; they would be at the age of the best potential as cellulosic raw material.

Fiber length, width, and wall thickness were measured for disaggregates of each species (Fig. 2). Fiber length and width data were obtained using the FQA-360 Fiber Quality Analyzer. Besides, fiber width and lumen were measured using an optical microscope. Another morphological characterization of the fibrous and non-fibrous structural elements of the bamboo was carried out by observing the histological sections of the stem.

The average fiber length and width values are shown in Table 2. The fiber length of $G$. angustifolia was $1.441 \mathrm{~mm}$. Although this value is close to some reported values $\left(1.491 \mathrm{~mm}^{20}\right.$ and $1.60 \mathrm{~mm}^{21}$ ), it is significantly below others found in similar studies $(2.70 \mathrm{~mm}){ }^{22}$ The fiber length of $G$. trinii was $1.044 \mathrm{~mm}$, significantly shorter than that of the G. angustifolia fibers.

The cell wall is composed of several layers, and the S2 is the most important in terms of mechanical strength because it accounts for 75-
$85 \%$ of the total thickness, with high cellulose content (around 50\%). Fiber dimensions (fiber length and diameter, lumen width, and wall thickness) are variables influencing various physical, mechanical, and structural properties of products obtained from wood or non-wood raw materials (panels, pulps, paper, and board). The effect of fiber dimensions and morphology on specific mechanical properties of paper have been characterized by the flexibility coefficient, felting index, and Runkel ratio, among other biometric parameters, to establish their suitability for the manufacture of cellulosic pulp. The length is key to forming the fiber network. Long fibers affect the tear strength and produce a more open and less uniform sheet structure. A high flexibility coefficient leads to good fiber bonding, positively influencing burst strength, tensile strength, and folding endurance of paper. The Runkel ratio should be lower than one. A higher value means stiff fibers, with poor fiber-fiber bonding capacity.

The characteristics of bamboo stem fibers present variations among species, which results in different mechanical strengths, allowing varied uses. Thus, these parameters help predict density, volume, tensile strength, compression, and other properties. However, all parameters must be carefully evaluated to have the right idea of the future paper behavior.

The aptitude for pulp and paper production of the fibers of both bamboo species can be estimated from the biometric relationships: flexibility coefficient $(\mathrm{Fc})$, felting index $(\mathrm{Fel})$, and Runkel ratio (R) (Table 2), which are calculated from the dimensions of the fibers. The parameters for $G$. angustifolia fibers $(\mathrm{F}>50, \mathrm{Fel}>70)$ indicate good pulp strengths (mainly tensile, burst, and tear) and good paper formability $(0.25$ $<\mathrm{R}<0.5$ ). However, G. trinii fibers could 
produce papers with good tear strengths $(\mathrm{F}<50$, Fel > 70), but its thick walls prevent their collapse, leading to poor fiber-fiber boding ( $\mathrm{R}>$ 2.00). ${ }^{23}$

In general, bamboo species have a fiber length similar to that of hardwoods $(0.8$ to $1.5 \mathrm{~mm}){ }^{20}$ Both bamboo species analyzed in this study present average lengths within the range indicated for hardwood ones. However, compared with other bamboo species, the literature presents a wide range of variations. Bambusa spp. show higher values than the average fiber length obtained in this study; however, the average fiber width is lower. ${ }^{20,24}$ The results obtained in this study were similar to those reported for Bambusa species (1.2 mm length, $10 \mu \mathrm{m}$ width) ${ }^{25}$ and Phyllostachys (1.6 mm length, $9.753 \mu \mathrm{m}$ width) ${ }^{20}$

Width values varied depending on the measurement method (Table 2). The average width measured by FQA-360 was two-fold that obtained by optical microscopy, since the FQA-

Average length and width measured by FQA-360 and average width and wall thickness measured by optical microscopy (measurements number: 200), and biometric relationships

\begin{tabular}{lcccccccc}
\hline \multirow{2}{*}{ Species } & \multicolumn{2}{c}{ FQA-360 } & \multicolumn{3}{c}{ Optical microscopy } & F & Fel & $\mathrm{R}$ \\
\cline { 2 - 8 } & $\mathrm{L}(\mathrm{mm})$ & $\mathrm{W}(\mu \mathrm{m})$ & $\mathrm{W}(\mu \mathrm{m})$ & $1(\mu \mathrm{m})$ & $\mathrm{W}(\mu \mathrm{m})$ & $\left(\mathrm{l} / \mathrm{W}^{*} 100\right)$ & $(\mathrm{L} / \mathrm{W})$ & $(2 \mathrm{w} / \mathrm{l})$ \\
\hline G. trinii & $1.044^{a}$ & $24.4^{c}$ & 10.6 & 3.00 & 3.78 & 28 & 98 & 2.52 \\
G. angustifolia & $1.441^{b}$ & $22.0^{d}$ & 12.3 & 8.26 & 2.01 & 67 & 117 & 0.49
\end{tabular}

L: fiber length, W: fiber width, l: lumen width, w: wall thickness; Weighted in length: mm; ${ }^{\text {a }}$ Elapsed time (s): 703; Total fiber count: 31432; Actual fiber count: $4968^{\mathrm{b}}$ Elapsed time (s): 166; Total fiber count: 15389; Actual fiber count: 4968. Weighted in length: $\mu \mathrm{m},{ }^{\mathrm{c}}$ Elapsed time (s): 703; Total fiber count: 4968; Actual fiber count: $1310^{\mathrm{d}}$ Elapsed time (s): 166; Total fiber count: 5007; Actual fiber count: 3240
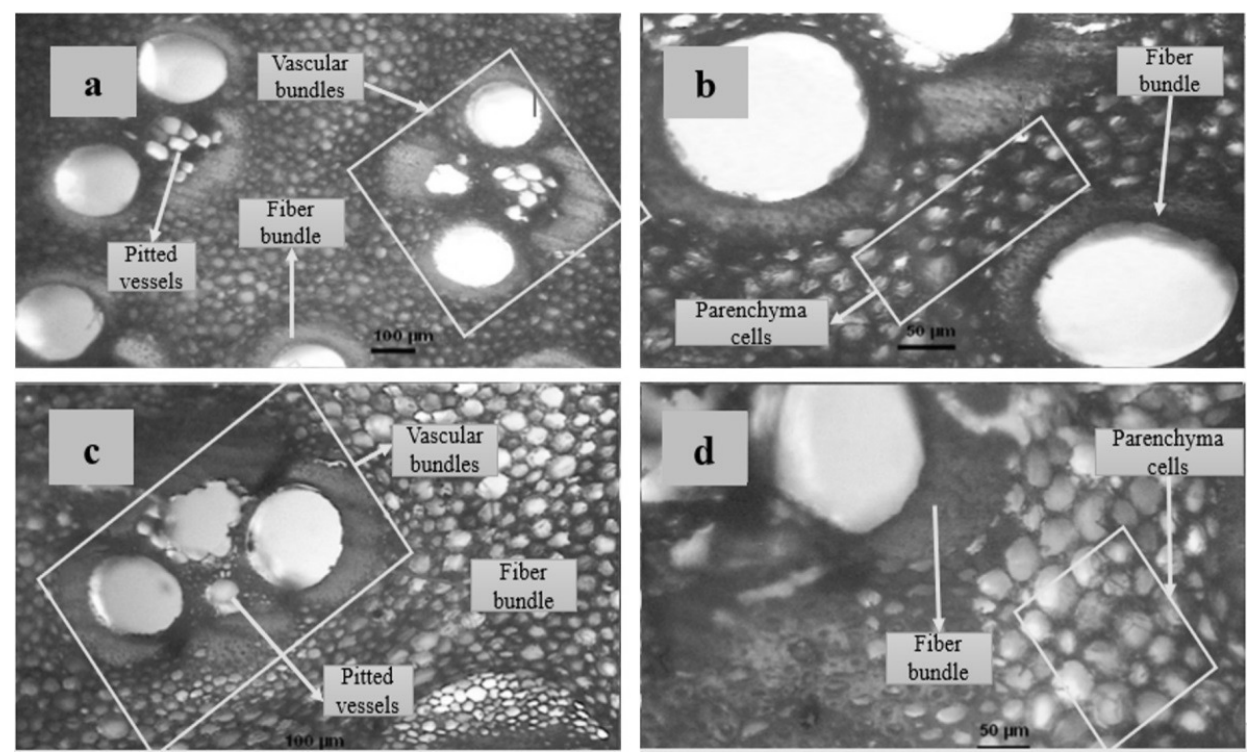

Figure 3: Distribution of fibers and vascular bundles in bamboo cross-section: a. G. trinii (10X), b. G. trinii (40X), c. G. angustifolia (10X), d. G. angustifolia (40X) 

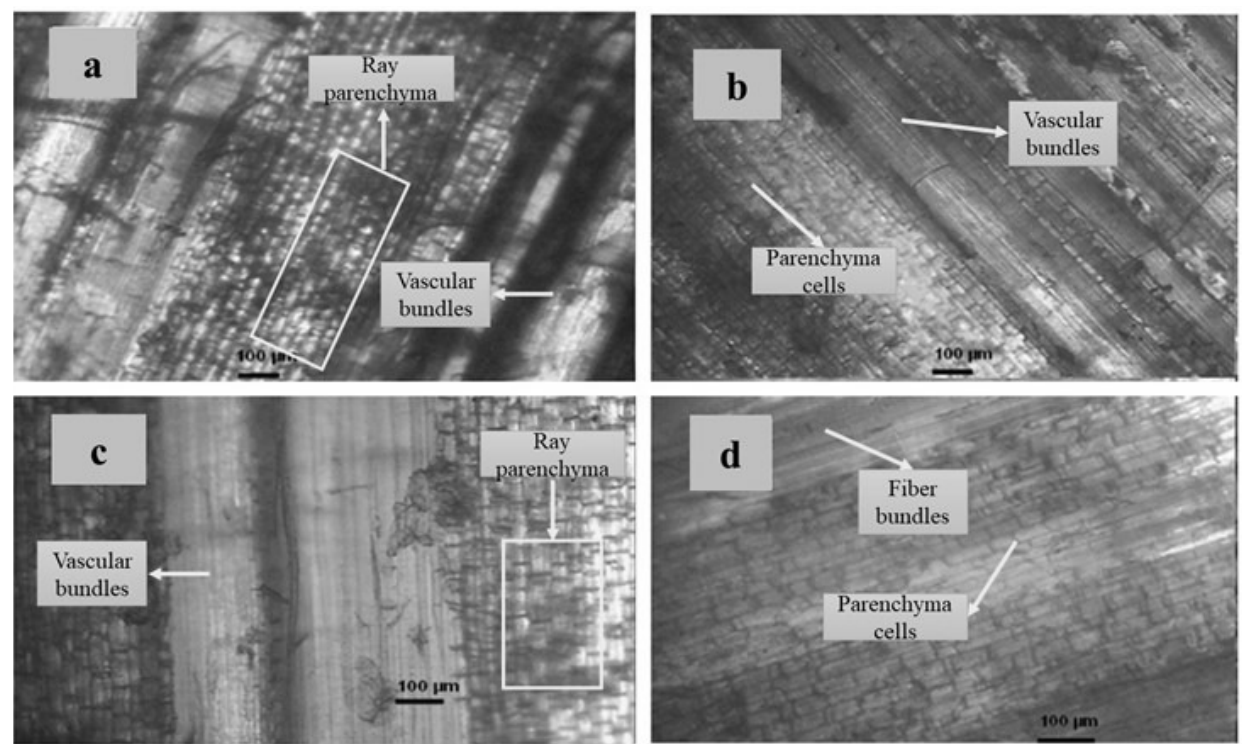

Figure 4: Bamboo structure: a. Radial section (10X) of G. trinii, b. Radial section (10X) of G. angustifolia, c. Longitudinal section (10X) of G. trinii, d. Longitudinal section (10X) of G. angustifolia

Table 3

Extractives and ash contents (\% on dry weight of the unextracted sample)

\begin{tabular}{lcc}
\hline Components & G. trinii & G. angustifolia \\
\hline Total extractives $(\%)$ & 8.67 & 9.55 \\
- Benzene alcohol (\%) & 6.05 & 5.72 \\
- Hot water (\%) & 2.62 & 3.83 \\
Ash (\%) & 4.58 & 4.05 \\
\hline
\end{tabular}

The internal structure of bamboos consists of a parenchyma matrix surrounding the vascular bundles, which are composed of conductive tissue, parenchyma cells, and fibers. ${ }^{26}$ Generally, the percentage of fiber decreases from the external to the internal culm wall and the parenchyma amount is higher in the interior. ${ }^{21}$ The cross-section appearance depends on the shape, size, number, and concentration of vascular bundles. Near the periphery, vascular bundles are small, numerous, and concentrated, while in the middle part of the culm, they are larger and more widely distributed. ${ }^{27}$

Guadua angustifolia is composed of $51 \%$ parenchyma tissue, $40 \%$ fibers, and $9 \%$ conductive tissue. The conductive tissue of the culm wall is composed of sclerenchyma cells, vessels, and sieve tubes with accompanying cells. In addition, in a cross-section of the culm, four zones are differentiated, whose differences are due to the shape and size of the vascular bundles in each of them: a) periphery, which corresponds to $4.5 \%$ of the wall thickness of the culm; b) transition, which corresponds to $10.7 \%$; c) medium, which corresponds to $73.9 \%$, and d) internal, which corresponds to $10.8 \%$ of the thickness of the culm wall. ${ }^{28}$

The chemical composition of bamboo is similar to that of hardwoods, except for ash and extractives, which present higher values. ${ }^{29}$ The bamboo culm consists mainly of cellulose, hemicelluloses, and lignin, containing other components, such as extractives and inorganic components (ash) in smaller proportions. ${ }^{30}$ Table 3 presents the extractives and ash contents, expressed in percentage on the dry weight of the unextracted sample. Table 4 shows the lignin and structural carbohydrates contents for both species, based on the dry weight of the extracted sample. The complete chemical characterization of both species, based on the dry weight of the unextracted sample, is shown in Table 5.

The total extractives were $8.67 \%$ and $9.55 \%$ for G. trinii and G. angustifolia, respectively. The ash contents were similar for both species $(G$. trinii $-4.58 \%$ and G. angustifolia $-4.05 \%$ ). The ash content reported in the bibliography ranges from $3.80 \%$ to $5.85 \%,{ }^{31-34}$ similar to that 
determined for G. angustifolia species. However, some authors reported diverse values for extractives (19\% total extractives), ${ }^{35}$ ethanol extractives $(6.47 \%$ and $7.54 \%),{ }^{31,32}$ and benzenealcohol extractives $(0.89 \%){ }^{34}$ For bamboo species, the values reported are $15.2 \%$ for extractives and lower ash contents, ranging from $0.5 \%$ to $6.2 \%$, for bamboos in general. ${ }^{20,30,35,36}$

In the bibliography, the chemical composition of bamboo is $45 \%$ cellulose, $23 \%$ hemicelluloses, and 22\% lignin. The reported carbohydrate content was similar to that obtained for $G$. trinii and slightly higher than that of $G$. angustifolia. The lignin content was close to values obtained for both species. ${ }^{30,36}$ Another reference indicated pentosan contents (xylans and arabinan) of $18.5 \%$ for Bambuseae and $20.17 \%$ for Phyllostachys, with lignin contents of $19.5 \%$ (Bambuseae) and $22.95 \%$ (Phyllostachys). ${ }^{20}$

Table 4

Lignin and structural carbohydrates contents (\% on dry weight of the extracted sample)

\begin{tabular}{lcc}
\hline Components & G. trinii & G. angustifolia \\
\hline Total lignin (\%) & 23.9 & 25.2 \\
- Insoluble lignin (\%) & 24.4 & 24.7 \\
- Soluble lignin (\%) & 1.39 & 1.10 \\
Total carbohydrates (\%) & 65.6 & 63.8 \\
- Glucans & 40.9 & 41.3 \\
- Xylans & 21.1 & 19.6 \\
- Arabinans & 0.62 & 0.74 \\
- Acetyl groups & 3.03 & 2.14 \\
\hline
\end{tabular}

Table 5

Chemical composition (\% on dry weight of the unextracted sample, corrected for ash and extractives)

\begin{tabular}{lcc}
\hline Components & G. trinii & G. angustifolia \\
\hline Carbohydrates & 65.6 & 63.8 \\
Total lignin & 23.9 & 25.2 \\
Total extractives & 8.67 & 9.55 \\
Ashes & 4.58 & 4.05 \\
\hline
\end{tabular}

Table 6

Potential bioproducts from bamboo, prices and application areas

\begin{tabular}{|c|c|c|c|}
\hline Components & Bioproducts & $\begin{array}{l}\text { Price } \\
\text { (USD/t) }\end{array}$ & Application areas \\
\hline \multirow{2}{*}{ Cellulose } & Nanocellulose & $\begin{array}{l}5,000- \\
10,000^{48}\end{array}$ & $\begin{array}{l}\text { Reinforcement of paper and cardboard, composites, } \\
\text { coatings, and cement. Porous and light materials, } \\
\text { modification of paints rheology, fillers in } \\
\text { pharmaceutical products etc. }\end{array}$ \\
\hline & $\begin{array}{l}\text { Levulinic } \\
\text { acid }\end{array}$ & $\begin{array}{l}4,000- \\
5,000^{49}\end{array}$ & $\begin{array}{l}\text { Food and cosmetic industries, organic perfumes, } \\
\text { skin conditioners, and pH regulators. Products } \\
\text { derived as gamma-valerolactone, adipic acid, and } \\
\text { others }\end{array}$ \\
\hline \multirow[b]{2}{*}{ Hemicelluloses } & Xylitol & $\begin{array}{l}2,000- \\
3,500^{49}\end{array}$ & $\begin{array}{l}\text { Sweetener for the food and pharmaceutical } \\
\text { industry, coating agent for pharmaceutical products }\end{array}$ \\
\hline & Furfural & $500-1,500^{49}$ & $\begin{array}{l}\text { The main end use of furfural is furfuryl alcohol } \\
\text { (almost } 90 \% \text { of total consumption). Other } \\
\text { applications are solvent, chemical, and } \\
\text { pharmaceutical products, flavoring intermediates }\end{array}$ \\
\hline Lignin & $\begin{array}{l}\text { Technical } \\
\text { lignin }\end{array}$ & $\begin{array}{l}1,300- \\
6,500^{50}\end{array}$ & $\begin{array}{l}\text { Dispersants (lignosulphonate), binders and } \\
\text { adhesives, chemicals etc. }\end{array}$ \\
\hline
\end{tabular}

Diversifying the conventional production of the non-wood pulp and paper industry using both bamboo species could be of help in improving profitability. The implementation of biorefineries 
would enable producing nanocellulose, biomaterials, fermentable sugars, and technical lignin., ${ }^{1,37}$ Bamboo hemicelluloses are mainly composed of xylans, a polymer formed of C5 sugar (xylose). Xylose is a relevant chemical building block with the capacity to generate lowmolecular-weight xylooligosaccharides, xylitol (sweeteners), furfural for furan resins, and furfuryl alcohol, liquid fuel, furfural (solvent), or chemicals. ${ }^{38-40}$ Besides, the cellulosic fraction can be a source of new biomaterials, such as nanocrystals, nanocellulose, or composites, fermentable C6 sugar, and levulinic acid. ${ }^{39,41-44}$ The lignin-rich black liquor from bamboo pulping has potential use as a phenolic building block for fine chemical and resin production. ${ }^{45-47}$ Some potential high-value products from bamboo, prices, and markets are shown in Table 6.

\section{CONCLUSION}

The densities of $G$. angustifolia are more significantly different in different parts of the same individual. Both species have densities that are within the adequate range for the pulp industry. Fibers of G. angustifolia have a greater average length (over $1 \mathrm{~mm}$, similarly to hardwoods, such as Eucalyptus), but slightly lower wall thickness.

Both species have similar carbohydrate contents, somewhat higher in G. trinii. The hemicelluloses content was also comparable in both species, comprising mainly xylans. The lignin and extractives contents of $G$. trinii were slightly lower. The ash content of both species was similar and relatively high, compared to other conventional paper raw materials.

Biometric relationships allow estimating that only $G$. angustifolia could produce good quality chemical pulps, with good pulp strengths and paper formability. However, G. trinii could be a raw material for high-value products by its fractionation into cellulose, hemicelluloses, and lignin, in a biorefinery framework.

\section{REFERENCES}

1 M. C. Area and M. E. Vallejos, in "Biorrefinerias a partir de recursos lignocelulosicos", edited by M. C. Area and M. E. Vallejos, Editorial Académica Española, 2012, pp. 1-15

${ }^{2}$ E. J. Trigo, A. Mentaberry, E. J. Cap, A. Zelada and F. Villarreal, "El potencial de la bioeconomía y las biorrefinerías en la argentina", Argentina, December, 2011, pp. 1-36, https://www.argentina.gob.ar/sites /default/ files/biorrefinerias-doc.pdf
B. Kamm, P. R. Grubber and M. Kamm, in "Biorefineries - Industrial Processes and Products", edited by B. Kamm, P. R. Grubber and M. Kamm, Wiley-VCH Verlag GmbH \& Co. KGaA, 2006, pp. 340, https://doi.org/10.1002/9783527619849.ch1

4 FAO Departamento Forestal Dendroenergía, in "Análisis del Balance de Energía derivada de Biomasa en Argentina", WISDOM Argentina, Final Report, Argentina, May, 2009, https://www.produccionanimal.com.ar/Biodigestores/41-balance_energia.pdf

5 V. S. Chauhan and S. K. Chakrabarti, Cellulose Chem. Technol., 46, $389 \quad$ (2012), https://www.cellulosechemtechnol.ro/pdf/CCT56(2012)/p.389-400.pdf

6 V. I. Popa, in "Pulp Production and Processing: From Papermaking to High-Tech Products", edited by V. I. Popa, Smithers Rapra Technology Ltd., 2013, pp. 520

7 J. E. G. Van Dam, H. W. Elbersen and C. M. Daza Montaño, in "Bamboo Production for Industrial Utilization in Perennial Grasses for Bioenergy and Bioproducts", edited by E. Alexopoulou, Academic Press Ed. Elsevier, 2018, pp. 175-216

8 L. Parodi, Rev. Argent. Agron, 3, 229 (1936)

9 A. Burkart, in "Flora ilustrada de Entre Rios", Instituto Nacional de Tecnología Agropecuaria, 1969, pp. $1-551$

${ }^{10}$ E. Nicora and Z. Rúgolo de Agrasar, "Los géneros de Gramíneas de América Austral", Hemisferio Sur, 1987, pp. 1-611

11 L. Smith, D. Wasshaussen and R. Klein, in "Flora Ilustrada Catarinense", edited by R. Reitz, Ed. Santa Catarina, 1981, pp. 1-435

12 UNALM PERÚ, Internal Report of the Círculo de Investigación del Bambú, Lima, 2016

13 M. Lizarazuru, Thesis, Facultad de Ciencias Exactas y Naturales, Universidad de Buenos Aires, Buenos Aires, 2013, https://bibliotecadigital.exactas.uba.ar/download/tesis/t esis_n5252_Lizarazu.pdf

14 S. Nahar, R. A. Khan and K. Dey, J. Thermoplast. Compos. Mater., 1, $15 \quad$ (2012), https://doi.org/10.1177/0892705711404725

15 Y. Yu, H. K. Wang and F. Lu, J. Mater. Sci., 6, 2559 (2014), https://doi.org/10.1007/s10853-0137951-z

16 X. Londoño, Internal Report "Evaluation of Bamboo Resources in Latin America”, Cali, 1998

17 T. Werh and L. Barrichelo, O Papel, 5, 33 (1993)

18 R. Gomide, J. Colodette and J. Oliveira, in Procs. Congr. Anu. da ABCP, São Paulo, November 22-26, 1982, pp. 189-203

19 R. Wahab, A. Mohamad, H. Samsi, A. Yunus and J. Moktar, J. Plants Sci., 1, 144 (2006), https://doi.org/10.3923/jps.2006.144.153

20 J. Haun, T. Clark and G. White, "Fiber and Papermaking Characteristics of Bamboo", Technical $\begin{array}{llll}\text { Bulletin } & \mathrm{N}^{\circ} & 1361, & 1966 \text {, }\end{array}$ https://doi.org/10.22004/ag.econ.171450 
21 W. Liese, "The Anatomy of Bamboo Culms", INBAR, 1998, pp. 1-204

22 M. Rubio, Thesis, Universidad Nacional Agraria La Molina, Lima, 2017, pp. 33-35

23 M. C. Area and V. I. Popa, "Wood Fibers for Papermaking", Smithers Rapra Technology, 2014, pp. 106

24 Z. Egbewole, O. Rotowa and P. Omoake, PAT Niger., 11, 188 (2015)

25 L. Rodriguez and H. Cáceres, Thesis, Universidad Industrial de Santander, Bucaramanga, 1982

26 J. Osorio, Thesis, Universidad Nacional de Colombia, Medellin, 2006, https://repositorio.unal.edu.co/bitstream/handle/unal/60 134/71756431.2006.pdf? sequence $=1 \&$ isAllowed=y

27 D. Groser and W. Liese, Wood Sci. Technol., 5, 290 (1971), https://doi.org/10.1007/BF00365061

28 X. Londoño, N. Riaño, and G. Camayo, in "Estudio anatómico de los diferentes órganos de la guadua (Guadua angustifolia Kunth), con énfasis en el culmo", Report, Corp. Reg. Autónoma de Quindío, Chinchiná, 2002

29 N. Marinho, Thesis, UTFPR, Curitiba, 2012, pp. 141

30 D. Fengel and G. Wegener, "Wood: Chemistry, Ultrastructure, Reactions", Walter de Gruyter \& Co., 1989, pp. 613

31 G. R. Gutiérrez Tejada, Thesis, Facultad de Ciencias Forestales de la Universidad Nacional Agraria La Molina (FCF-UNALM), Lima, 2015

32 A. Cuéllar and I. Muñoz Cuervo, DYNA-Revista la Fac. Minas, 77, 137 (2010)

33 C. I. Chiluiza and J. Hernández, "Elaboración de papel artesanal de caña guadua (Guadua angustifolia K.)", Report, Escuela Politécnica Nacional, Quito 2009, pp. $1-15$

34 H. E. Gonzales Mora, Thesis, UNALM, Lima, 2002

35 J. Otavio, M. Tomazello and A. Luiz de Barros, "Producción y caracterización del carbón vegetal de especies y variedades de Bambú", IPEF, Piracicaba, 1987

36 H. Kleine and C. Foelkel, CI Florestas, March, 2012.

37 M. Brodin, M. Vallejos, M. T. Opedal, M. C. Area and G. Chinga-Carrasco, J. Clean. Prod., 162, 646 (2017), https://doi.org/10.1016/j.jclepro.2017.05.209
38 M. E. Vallejos, F. E. Felissia, J. Kruyeniski and M. C. Area, Ind. Crop. Prod., 67, 1 (2015), https://doi.org/10.1016/j.indcrop.2014.12.058

39 M. Vallejos, F. Felissia, M. C. Area, N. Ehman, Q. Tarrés et al., Carbohyd. Polym., 139, 99 (2016), https://doi.org/10.1016/j.carbpol.2015.12.004

40 M. E. Vallejos, M. D. Zambon, M. C. Area and A. A. da Silva Curvelo, Green Chem., 14, 1982 (2012), https://doi.org/10.1039/C2GC35397K

${ }^{41}$ Q. Tárres, N. V. Ehman, M. E. Vallejos, M. C. Area, M. Delgado Aguilar et al., Carbohyd. Polym., 5, 20

(2017),

https://doi.org/10.1016/j.carbpol.2017.01.017

42 M. E. Vallejos, M. S. Peresin and O. J. Rojas, J. Polym. Environ., 20, $1075 \quad$ (2012), https://doi.org/10.1007/s10924-012-0499-1

${ }^{43}$ N. M. Clauser, F. E. Felissia, M. C. Area, M. E. Vallejos and S. Gutiérrez, J. Clean. Prod., 257, 120549 , https://doi.org/10.1016/j.jclepro.2020.120549

(2020),

${ }_{44}$ L. G. Covinich, N. M. Clauser, F. E. Felissia, M. E. Vallejos and M. C. Area, Biofuel. Bioprod. Biorefin., 14, 1 (2020), https://doi.org/10.1002/bbb.2062

45 E. Felissia Fernando, E. María Vallejos and M. C. Area, Cellulose Chem. Technol., 44, 311 (2010), https://cellulosechemtechnol.ro/pdf/CCT9(2010)/p.311 -318.pdf

46 M. E. Vallejos, F. E. Felissia, A. A. S. Curvelo, M. D. Zambon, L. Ramos et al., BioResources, 6, 1158 (2011), https://bioresources.cnr.ncsu.edu/wpcontent/uploads/2016/06/BioRes_06_2_1158_Vallejos _FCZRA_Chem_PHys_Char_Lignins_Frac_Bagasse_ 1398.pdf

47 M. E. Vallejos, M. D. Zambon, M. C. Area and A. A. D. S. Curvelo, Ind. Crop. Prod., 65, 349 (2015), https://doi.org/10.1016/j.indcrop.2014.11.018

48 C. A. de Assis, C. Houtman, R. Phillips, E. M. Bilek, O. J. Rojas et al., Biofuel. Bioprod. Biorefin., 11, 682 (2017), https://doi.org/10.1002/bbb.1782

"49 Indufor North America LLC, "Global Market Analysis and Benchmarking Study. Phase 1: Global Market Analysis", Report, Washington \& Auckland, July, 2018, 2 http://formaine.org/wpcontent/uploads/2020/09/Indufor-Phase-1-Report20180917.pdf

50 T. Kraia, M. Bampaou, K. D. Panopoulos and S. Voutetakis, in Procs. $26^{\text {th }}$ European Biomass Conference and Exhibition, May, 2018, pp. 1099 